\title{
Ontginning van die groen goud van Suid-Afrika
}

Baie Suid-Afrikaners is bewus van die minerale skatte van Suid-Afrika en ook daarvan dat SuidAfrika een van die wêreldleiers is wat die tegnologie van ontginning van minerale rykdomme betref. Nie baie Suid-Afrikaners besef met watter rykdom van plante die Skepper Suid-Afrika toebedeel het nie. Onder plantkundiges is dit algemene kennis dat die 24000 verskillende blomplantsoorte wat in SuidAfrika voorkom, dit een van die rykste gebiede in die wêreld maak wat plante per oppervlakte-eenheid betref. Die feit dat daar ongeveer 250000 blomplantsoorte in die wêreld voorkom en bykans $10 \%$ daarvan in so 'n klein landjie soos Suid-Afrika, wys op die buitengewone rykdom waaroor ons hier beskik. Carolus Linnaeus, waarskynlik een van die grootste plantkundiges van alle tye, het in 'n brief aan sy vriend Rijk Tulbagh, destyds goewerneur aan die Kaap, geskryf dat indien hy (Linnaeus) die kans gehad het om plekke te ruil met Aleksander die Grote, Salomo, Croesus of Tulbagh, hy onmiddellik sou kies om met Tulbagh plekke te ruil, omdat Tulbagh die wonderlike voorreg gehad het om in 'n land te woon met so 'n fantastiese planterykdom. Baie mense weet reeds dat die winterreënvalgebied van die Kaap as een van die ses Plantkoninkryke van die wêreld beskou word. Mense besef egter nie dat die res van Suid-Afrika net so 'n rykdom aan plante as die Suidwes-Kaap het nie.

In teenstelling met die ontginning van ons minerale rykdomme, is baie min aandag in Suid-Afrika bestee aan die ontginning van ons ander groot natuurlike bate: ons planterykdom. Om die waarheid te sê, in groot mate is baie van hierdie plante deur mense in die buiteland ontgin en tot hulle eie voordeel aangewend. Daar is ook 'n lang lys tuinplante wat in die buitewêreld veredel en met groot finansiële voordele vir die betrokke lande bemark is. Baie min mense in die buitewêreld besef vandag dat die volgende algemene tuinplante van Suid-Afrikaanse oorsprong is: Gladiolus, Kniphofia (vuurpyl), Pelargonium (malva), Freesia, Tritonia, Sparaxis, Gerbera, Strelitzia, Plumbago, Tecomaria, Agapanthus, Streptocarpus, Nemesia en nog talle ander. Dit is ironies dat die Strelitzia as die nasionale blom van Kalifornië in die VSA beskou word.

In hierdie bespreking gaan daar eers gekyk word na die waarde wat plante vir die mens kan hê, daarna na die groot dreigement wat die uitwissing van plantlewe vir die mens inhou, en ten slotte na wat in SuidAfrika gedoen word of gedoen behoort te word om plantmateriaal tot die voordeel van die mense van Suid-Afrika aan te wend.

\section{Plante se gebruik as voedsel}

Die belangrikste waarde wat plante vir die mens het, is ongetwyfeld dat dit ' $n$ basiese voedselbron is.
Alhoewel daar na beraming ongeveer 80000 eetbare plante in die wêreld is, word $95 \%$ van al ons voedingsbehoeftes uit 30 plantsoorte verkry, $75 \%$ uit agt plantsoorte en meer as $50 \%$ uit net drie plantsoorte (mielies, rys en koring). In die sogenaamde groen revolusie het die mens daarin geslaag om baie hoër plantopbrengste te verkry deur die omgewing so te verander dat plante baie beter kan groei. Ongelukkig het die hoë koste van water en kunsmis daartoe gelei dat in veral die arm lande die voordeel van die groen revolusie nie ten volle uitgebuit kon word nie. Met die dramatiese bevolkingsaanwas oor die hele wêreld heen, begin voedselvoorsiening 'n al groter probleem word.

Dit is verbasend dat met so 'n groot aantal plantsoorte wat beskikbaar as voedselbronne is, daar van so min plantsoorte gebruik gemaak word. Deur seleksie en hibridisering is die dertigtal plantsoorte wat vandag algemeen gebruik word, deur die eeue heen ontwikkel. Dit is asof die mens nie besef dat daar soveel ander plantsoorte is wat ook op hierdie wyse ontwikkel kan word nie. Met die moderne tegnologie is dit nie slegs moontlik om deur kruising en seleksie plante baie vinniger te ontwikkel nie, maar dit is selfs moontlik om deur die manipulering van die erflike materiaal plante te ontwikkel wat oor die wenslike eienskappe beskik.

Een van die groot probleme met die plantsoorte wat tans as voedselbron gebruik word, is dat plante voortdurend geteel moet word wat bestand is teen insekte of patogene wat die plant aanval. Indien die genetiese diversiteit wat teenwoordig is in die primitiewe rasse van daardie plante, verlore sou gaan, kan dit wees dat wetenskaplikes nie die gewenste genetiese kenmerke in die ontwikkelde plantsoort kan terugteel nie. Die ontstaan van 'n nuwe soort patogeen kan daartoe lei dat 'n geweldige groot oesskade gely word. Uit die geskiedenis is dit reeds bekend watter geweldige gevolge die afsterwing en mislukking van die aartappeloes op die bevolking in Ierland gehad het. Daarom is dit baie belangrik om die voorouers van voedselplante te bewaar, sodat die genetiese diversiteit beskikbaar is om tot voordeel van die mens aańgewend te word. Dit is byvoorbeeld bekend dat 'n enkele populasie van rys in Sentraal-Indië die enigste bekende bron van weerstand teen ' $n$ baie belangrike rysvirussiekte was. Weerstand is van hierdie skaars plant ingeteel in die ryskultivar IR 36, wat sedertdien die mees algemeen gebruikte ryskultivar geword het.

\section{Plante se gebruik in medisyne}

Die medisinale waarde van plante is iets wat nie onderskat moet word nie. Ongeveer $75 \%$ to $90 \%$ van die wêreld se landelike bevolkings gebruik plante as hulle primêre bron van medisyne. Sedert 1978 het 
die Wêreldgesondheidsorganisasie 20000 plantsoorte met medisinale waarde geïdentifiseer, waarvan 200 op 'n kortlys vir uitgebreide studie geplaas is. 'n Beraming van die VVO het aangedui dat die markomset in medisinale plante in 1980 ongeveer $\$ 550$ miljoen was.

Wat konvensionele medisyne betref, word ongeveer $40 \%$ van die geneesmiddels wat in die wêreld gebruik word, van plante verkry; of die aktiewe bestanddeel wat oorspronklik in 'n plant geïdentifiseer is, word in laboratoriums gesintetiseer. Die totale waarde van hierdie komponente is ongeveer $\$ 40$ miljard per jaar. Aspirien (asetielsalisielsuur) is byvoorbeeld vir die eerste keer in die bas van wilgers ontdek. Alhoewel dit tans sinteties vervaardig word, sou dit nie ontdek gewees het as die gebruik van wilgerbas as pynstillende middel nie ondersoek is nie.

\section{Plante se gebruik in die nywerheid en as bron van energie}

Plante voorsien in 'n groot aantal van die mens se behoeftes. Benewens die voor die handliggende gebruik soos voedsel, konstruksiemateriaal en medisyne, word verskillende produkte, soos wasse, olies, gomme en geurmiddels, ook van plante geproduseer. Die groot voordeel om plante ook as bron van industriële materiaal te gebruik, is dat dit 'n hernubare bron is in teenstelling met olie of steenkool.

Omdat daar gedurig kompetisie tussen plante en sekere patogene is, het plante 'n verskeidenheid chemiese verbindings as wapens geproduseer. Sekere van hierdie verbindings kan tot groot voordeel van die mens aangewend word. ' $n$ Voorbeeld is die insektisied piretrien wat in Chrysanthemum ontdek is. Hierdie verbinding is nie toksies vir soogdiere nie, maar dit is baie giftiger vir vlieënde insekte as selfs DDT. Chrysanthemum word tans deur ongeveer 200000 boere oor die wêreld geproduseer.

Plante is natuurlik ook 'n bron van energie. Benewens hout, is steenkool en olie ook van plante afkomstig. Ook ander verbindings, soos rubber, olies en wasse, is baie belangrike industriële chemikalieë wat van plante afkomstig is. Daar word tans taamlik aktief oor guayule gewerk omdat die plant ' $n$ belangrike hernubare bron van rubber in ariede gebiede kan wees.

\section{Die tuinboukundige gebruik van plante}

Plante speel ' $n$ baie belangrike rol in die lewe van die mens as ontvlugting van spanning. Tuinmaak is een van die groeiende bedrywe in ontwikkelende bevolkings. In hierdie verband is Suid-Afrika geseèn met ' $n$ fabelagtige skat van plante met besonder groot tuinboukundige waarde. Suid-Afrika word ook baie gereeld deur buitelandse tuinboukundiges besoek en daar word sterk pogings aangewend om SuidAfrikaanse plante in die buiteland te veredel omdat dit 'n groot bron van inkomste kan wees. Daar is gesê dat die inkomste wat uit Suid-Afrikaanse plante in die buiteland verdien word, hoër is as wat die totale gouduitvoerinkomste van Suid-Afrika is. Dit is onrusbarend dat Suid-Afrika toelaat dat so baie van hierdie plante met 'n sterk ekonomiese potensiaal na die buiteland uitgevoer word en dan daar verder ontwikkel en ook ekonomies ontgin word.

'n Goeie voorbeeld is die noem-noem (Carissa macrocarpa), waarvan die saad uit Suid-Afrika na Kalifornië uitgevoer is, waar groot hoeveelhede van hierdie plant aangeplant is. 'n Ondernemende persoon het opgemerk dat een van die plante laag op die grond gegroei het, in teenstelling met al die ander plante. Hy het onmiddellik die potensiaal daarin gesien en die plant gepatenteer as ,,green carpet", met die gevolg dat daardie enkele plant tans op alle kontinente van die wêreld algemeen deur landskapargitekte gebruik word, met 'n inkomste van miljoene rande vir die patenteerder. In Suid-Afrika moet ons dus nou betaal om hierdie plant ook te kan gebruik. Dit het gebeur terwyl sulke laaggroeiende vorme in SuidAfrika self voorkom, maar ons mense nie die insig gehad het om die ekonomiese potensiaal daarvan te besef nie. Dit was veral die Hollanders wat baie sukses met ons bolplante behaal het en tans is die Israeli's en die Japannese ook baie bedrywig met SuidAfrikaanse plante.

Die oplossing van die probleem is nie om te probeer om alle Suid-Afrikaanse plante met alle mag in Suid-Afrika te hou nie, omdat dit onprakties is om te verhoed dat enkele plante of enkele saad na die buitewêreld vervoer word. Die oplossing is eerder dat Suid-Afrika moet begin aandag gee aan die ontginning van hierdie wonderlike ekonomiese bron.

\section{Wat word in Suid-Afrika gedoen?}

Verskillende aspekte kry in Suid-Afrika aandag. Wat voedselplante betref, word daar by die Voedingsnavorsingsinstituut van die WNNR ' $n$ aansienlike hoeveelheid werk gedoen oor die voedingspotensiaal van inheemse plante. By die Universiteit van Pretoria word die veredeling van die maroela, wat 'n belangrike eetbare plant is, tans onderneem. Wat die medisinale waarde van plante betref, is daar aansienlike werk oor 'n lang termyn op kontrakbasis deur die Nasionale Chemiese Navorsingslaboratorium van die WNNR vir buitelandse maatskappye gedoen. Van hierdie maatskappye het ook in Suid-Afrika takke, waar daar belangrike werk gedoen word om SuidAfrikaanse plante te evalueer vir byvoorbeeld kankerwerende eienskappe. Ongelukkig word baie van hierdie resultate nooit gepubliseer nie omdat dit so 'n groot ekonomiese voordeel vir die betrokke maatskappy kan hê.

Wat die ontginning van die tuinboukundige potensiaal betref, word goeie werk by die Tuinbounavorsingsinstituut by Roodeplaat gedoen. Alhoewel die meeste van die aktiwiteite van die Instituut toegespits is op ander nie-inheemse tuinboukundige plante wat alreeds op groot skaal in Suid-Afrika geplant word, word daar tog werk gedoen oor die teling van nuwe variëteite van byvoorbeeld Lachenalia-soorte, en daar word ook uitstekende werk oor die veredeling van proteas gedoen.

Met die eenparige aanvaarding van die Boswet deur die Parlement in 1984, is daar besef dat daar 'n taamlike groot leemte in hierdie verband bestaan. 
Gevolglik is een van die opdragte aan die Nasionale Botaniese Tuine (NBT), wat as 'n statutêre Raad deur die Boswet ingestel is, ,om die ekonomiese potensiaal van inheemse plante te benut, en om die benutting daarvan te bevorder"'. Gevolglik sien die NBT dit as een van sy groot uitdagings om hierdie saak -verder te ontwikkel. Die groot belangstelling wat onlangs in die gebruik van inheemse plante ontstaan het, maak hierdie kwessie 'n baie groot verantwoordelikheid. Die saak word verder in 'n latere uitgawe van die tydskrif bespreek.

\section{Waarom moet plante bewaar word?}

Die ontstellende wêreldwye bevolkingsontploffing het katastrofiese gevolge vir die bewaring van plantsoorte. Omdat al hoe groter gebiede nodig word vir die voorsiening van voedsel, word daar veral in die tropiese gebiede al hoe meer en meer habitatte uitgewis. Dit lei tot die uitsterwing van groot getalle plantsoorte. Daar is al bereken dat tot soveel as 40000 spesies binne die volgende 70 jaar kan uitsterf. Afgesien van die feit dat die wêreld baie oninteressanter sal wees as eensesde van sy plantsoorte sou uitsterf, is die grootste verlies natuurlik die moontlike waarde wat hierdie plante vir die mens sou kon gehad het.

Ook in Suid-Afrika neem die probleem ontstellende afmetings aan. Daar is byvoorbeeld bereken dat daar meer as 1900 plantsoorte in Suid-Afrika op die een of ander manier bedreig word. Suid-Afrika is, wêreldwyd gesien, inderdaad een van die gebiede waar die meeste werk oor die bewaring van plantsoorte vereis word. Die volgende aanhaling uit 'n besluit wat in November 1985 te Las Palmas geneem is, dui op die belangrike rol wat die plante in SuidAfrika, en veral van fynbosgebied, wêreldwyd het:

,Recognising the threat confronting many fragile ecosystems consisting of highly specialised and endemic floras; the International Conference on Botanic Gardens and the World Conservation Strategy: Calls upon governments, conservation organisations and aid agencies to support botanic gardens and related institutions involved with the most critically threatened plant ecosystems, particularly rain forests, wetlands, Mediterranean-type vegetation like the Cape Fynbos, and island ecosystems."

Dit is van die uiterste belang dat Suid-Afrika baie meer aandag moet gee aan die benutting van inheemse plante en veral aan die bewaring van plantsoorte wat in gevaar staan om uit te sterf. Dit is nie 'n taak wat deur een organisasie alleen aangepak kan word nie, maar dit vereis 'n spanpoging deur 'n groot aantal instansies beide in die staat-, parastatale en private sektore in Suid-Afrika. Alhoewel die probleme wat opgelos moet word, taamlik groot is, is die voordele wat met die oplossings bereik kan word van so 'n groot omvang vir Suid-Afrika dat dit hoë prioriteit behoort te geniet.

J.N. Eloff

Kirstenbosch 